\title{
Strategies for innovative teaching and learning Part 2: How to deliver a distance education online course
}

\author{
Constance E. McIntosh, Diana Bantz, Cynthia M. Thomas* \\ School of Nursing, Ball State University, USA
}

Received: March 9, 2021

Accepted: May 5, 2021

Online Published: May 16, 2021

DOI: $10.5430 /$ jnep.v11n9p39

URL: https://doi.org/10.5430/jnep.v11n9p39

\begin{abstract}
The second article in a three-part series discusses how to deliver a distance education online course by i) assuring understanding of the learning platform, ii) developing a course model, iii) creating individual assignment rubrics for courses, iv) requiring active participation from both instructor and students, and v) setting-up quality communication. This paper is a continuation of the first paper whereby the history of distance learning, the positives and negatives of online learning, advantages and disadvantages of online learning, and the initial considerations for establishing online courses.
\end{abstract}

Key Words: Online instruction, Innovative teaching, Teaching strategies, Online learning, Distance education

\section{INTRODUCTION}

Teaching and learning in a distance education modality is different than in a traditional on campus environment. Careful planning, access to experts in technology, defining the type of course to be delivered, and level of student experience will determine how courses are developed. Part-one of the threepart series discussed briefly the history of distance learning, the positives and negatives of online learning, advantages and disadvantages of online learning, and the initial considerations for establishing online courses. This second article continues a deeper discussion into how to deliver a distance education online course by i) assuring understanding of the learning platform, ii) developing a course model, iii) creating individual assignment rubrics for courses, iv) requiring active participation from both instructor and students, and v) setting-up quality communication (see Figure 1).

In order to deliver online education, one must know -and, have a working understanding - of the learning platform in their institutions. There are many types of online learning platforms including -but not limited to- learning destination sites, custom built platforms, and the traditional learning management system. Learning destination sites allows a faculty to author, create, and develop a course then upload that course to a larger user site for students to access. Learning destination sites are typically contracted by the educational institution. Diametric to learning destination sites are custom built platforms where the university faculty -not an outside entity-build all the technology needed for their course. When building the technology, the end product is considered including the overall pedagogy and the end user, for example the student or learner. Somewhere in the middle of the aforementioned platforms is the traditional learning management system where an outside-the-university vendor provides a basic template that allows faculty to develop online courses by authoring, adding content, provide learner feedback, and report grades.

After an extensive literature search using key words of elearning platforms, online learning platforms, learning man-

*Correspondence: Cynthia M. Thomas; Email: cmthomas@bsu.edu; Address: School of Nursing, Ball State University, USA. 
agement systems, or any/all combination of aforementioned searches, there was a dearth of information related to how the different platforms performed. Or, which platform allowed a better performance by students and faculty. Fundamentally, regardless of the platform used, to deliver distance education successfully, the faculty must have a working knowledge of the learning platform.

Strategies for Innovative Teaching and Learning
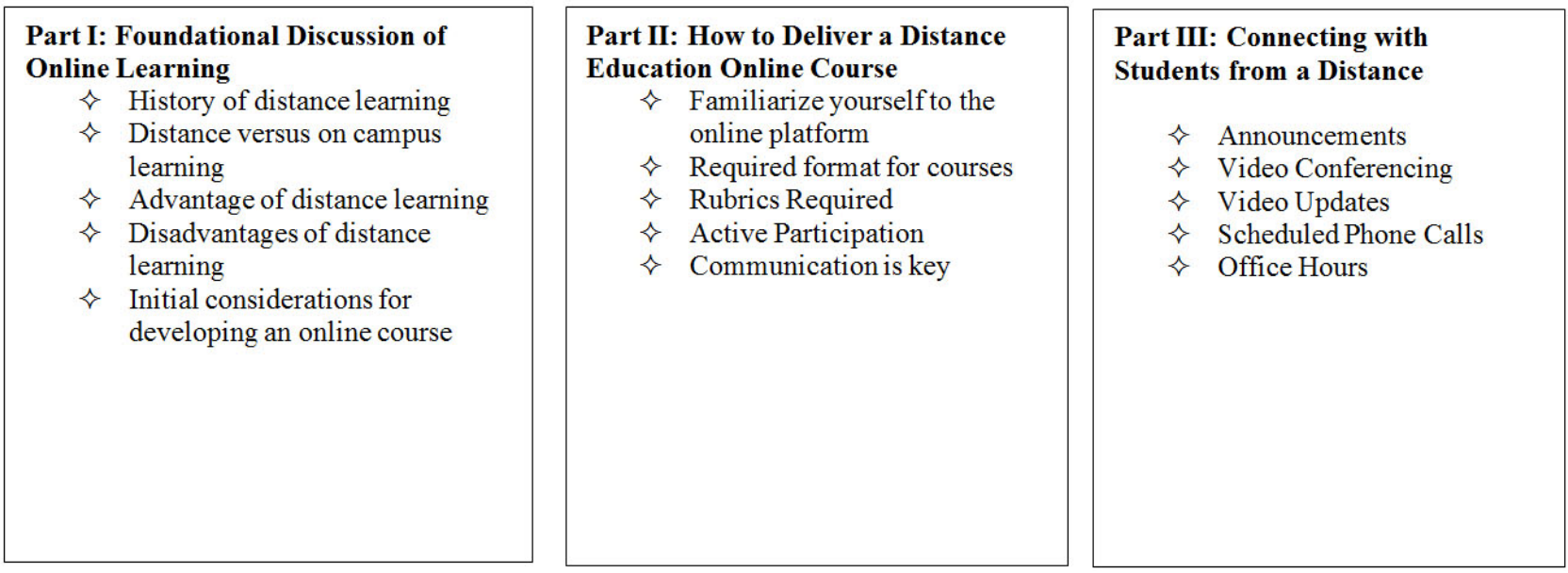

Figure 1. Strategies for innovative teaching and learning outline

\section{DEVELOPING A COURSE MODEL}

College students are overwhelmed by a plethora of stressors including social events, peer pressure, friendship development. ${ }^{[1]}$ Students report that a shift to online learning, due to the pandemic, has resulted in increased anxiety and depression. ${ }^{[2]}$ To counter undo stressors, faculty should mitigate as many anxiety-provoking variables as possible when developing online courses. Therefore, it is vital that developing a standard course model or template is essential during course development. Within most platforms, there are standard menu buttons - also-known-as buttons - in which students can choose from including grades, announcements, and lessons. Although some learning platforms come with standard buttons such as home, grades, assignments, and discussions these buttons can also be changed and customized according to faculty preference. Hara and $\mathrm{King}^{[3,4]}$ reported student stress may be linked to the inability to find information easily, missed due dates due to poor navigation paths through course material.

A standard course arrangement may improve course navigation for students, faculty, department, and the overall institution. For example, rather than allowing individual faculty options for button placement (grades, lessons), require all faculty to place the student buttons on the left-side of the screen. Furthermore, organize the buttons in a manner that makes sense to the student. Meaning, develop the course from the perspective of the student. Anecdotally, the first action that a student will do, when entering the course, is look for how the course is set-up. In this case, the buttons "communicate" where course information is located. It makes sense, to have the buttons easily recognizable and identifiable. Table 1 provides suggestions on organization of important buttons, what is located under each button, and how this can improve students' success.

\section{INDIVIDUAL ASSIGNMENT RUBRICS}

A rubric is a set of criteria or requirements used by faculty when grading assignments. Students use the rubric to identify expected outcomes of the assignment. Providing the assignment rubric at the beginning of the class allows the student to review and ask clarifying questions prior to the assignment due date. The benefit students receive from using the same instrument that faculty will eventually use when grading individual work is formative in nature. ${ }^{[5]}$ Rubrics provide the criteria established by the faculty for learning and grading of the assignment. Rubrics may also present the goals for a specific assignment and provides a place for faculty to give feedback to students. Rubrics can also be used to evaluate a students' clinical performance when including specific types of patients, clinical hours, practicing within legal boundaries, and adhering to professional standards and guidelines. ${ }^{[6,7]}$ At a minimum, a grading rubric should include the following: 1) performance criteria; 2) grading scale; and 3) indicators 
(UTA, 2017) ${ }^{[8]}$ but using evidence-based research to develop 2 provides an example of a grading rubric for with criterion. rubrics is a goal in delivering quality online learning. ${ }^{[9]}$ Table

Table 1. Course organization

\begin{tabular}{|c|c|c|}
\hline Organizing Menu Buttons & Type of Content or Information Located Here & How this Improves Students' Success \\
\hline Welcome/Greeting & $\begin{array}{l}\text { Include a welcome or greeting - either in written or video } \\
\text { format -- to the student, brief description of the course, } \\
\text { and biographical information about yourself. }\end{array}$ & $\begin{array}{l}\text { This simulates that in-class warm } \\
\text { welcoming atmosphere and introduces } \\
\text { the faculty as an approachable person. }\end{array}$ \\
\hline Announcements & $\begin{array}{l}\text { Used to communicate important information. For } \\
\text { example, a change in a due date or an assignment. }\end{array}$ & $\begin{array}{l}\text { Locating this button at the top of the } \\
\text { page will enforce to students to look at } \\
\text { announcements every time they log into } \\
\text { the course. }\end{array}$ \\
\hline $\begin{array}{l}\text { Syllabus and Course } \\
\text { Calendar }\end{array}$ & $\begin{array}{l}\text { Syllabus should include necessary information including } \\
\text { course rationale, descriptions, essentials, outcomes, and } \\
\text { policies. Course calendar should include } \\
\text { modules/lessons, assignments, and due dates/times. } \\
\text { Note: Make all assignments due the same date/time } \\
\text { during the week to reduce confusion for the students. }\end{array}$ & $\begin{array}{l}\text { The syllabus is the contract between the } \\
\text { faculty and student. Providing the } \\
\text { syllabus up front established the } \\
\text { educator/student relationship. } \\
\text { Assignments and due dates, located on } \\
\text { the course calendar, sets expectations } \\
\text { from beginning of course. Having } \\
\text { assignments posted the first day of the } \\
\text { course allows students to plan their } \\
\text { semester accordingly. }\end{array}$ \\
\hline Modules/Lessons & $\begin{array}{l}\text { Course content including lectures, written material, } \\
\text { accompanying documents, and assignments are located } \\
\text { here. }\end{array}$ & $\begin{array}{l}\text { Providing one central location for all } \\
\text { course material will lessen likelihood of } \\
\text { missed information. Students will know } \\
\text { exactly where to find course material. }\end{array}$ \\
\hline Grades & $\begin{array}{l}\text { Course grades are reported in this area. Feedback to } \\
\text { learner -written or video comments - are also located in } \\
\text { this area. }\end{array}$ & $\begin{array}{l}\text { Students will know where to find their } \\
\text { individual assignment grades and } \\
\text { overall course grades. Feedback on } \\
\text { assignments may also be located here. }\end{array}$ \\
\hline Assignment Rubrics & $\begin{array}{l}\text { Include all assignment rubrics. Make rubrics narrow } \\
\text { enough to guide a student to assignment requirements } \\
\text { but broad enough to allow for creativity and knowledge } \\
\text { understanding. }\end{array}$ & $\begin{array}{l}\text { Students will know expectations of } \\
\text { assignments, point values, and } \\
\text { assignment requirements. }\end{array}$ \\
\hline Student Success Tips & $\begin{array}{l}\text { Provide information that will lead to student success } \\
\text { such as contact information to writing center, adding due } \\
\text { date to their personal calendars, printing off syllabus, and } \\
\text { checking course announcements daily. }\end{array}$ & $\begin{array}{l}\text { Faculty that communicate tips for } \\
\text { student will have less questions } \\
\text { throughout the semester. }\end{array}$ \\
\hline
\end{tabular}

Another positive to adding rubrics to online learning platforms is the convenience for faculty during the academic year. Meaning, once rubrics are developed, they can be added to the platform's grade center area. Then, when grading, faculty can simply click on the rating of the student, and the grade will populate. This saves faculty time in writing narrative feedback to the student. Also, it saves faculty time in having to manually write a grade in the grade center area because once the grading rubric is completed the grade automatically populates.

\section{Active Participation}

The more student-to-student or student-to-faculty engagement implies a better experience for the student in an online Published by Sciedu Press environment. ${ }^{[10]}$ The focus of developing strong interprofessional relationships is within the environment where the relationships develop. ${ }^{[11]}$ Imogene King, a nursing theorist, understood that creating a safe environment allows for growth and learning. Historically, Peplau (1988) ${ }^{[12]}$ found developing a strong relationship was essential to providing quality patient care and the same strategy applies to interprofessional relationships with students. Given that nursing faculty have a similar educational relationship with their students, it makes sense to develop active participation for both student and faculty. This can be created in a variety of ways including group projects (shared beliefs, values), discussion boards, case studies, special projects (videos, presentations). 
Table 2. Rubric sample

\begin{tabular}{|c|c|c|}
\hline Discussion Board Criteria & Indicators/Ratings & Points \\
\hline $\begin{array}{l}\text { Initial post created with thoughtful answers related to the } \\
\text { prompt and assignment. }\end{array}$ & $\begin{array}{l}\text { Excellent }(20) \\
\text { Quality }(18-19) \\
\text { Good }(16-17) \\
\text { Fair }(14-15) \\
\text { Needs Improvement }(13 \text { or }<13)\end{array}$ & 20 \\
\hline $\begin{array}{l}\text { Response \#1 is made to classmate with the required length. } \\
\text { Response addresses the assignment requirement. }\end{array}$ & $\begin{array}{l}\text { Excellent (10) } \\
\text { Quality (9) } \\
\text { Good (8) } \\
\text { Fair (7) } \\
\text { Needs Improvement }(6 \text { or }<6)\end{array}$ & 10 \\
\hline $\begin{array}{l}\text { Response \#2 is made to classmate with the required length. } \\
\text { Response addresses the assignment requirement. }\end{array}$ & $\begin{array}{l}\text { Excellent }(10) \\
\text { Quality (9) } \\
\text { Good (8) } \\
\text { Fair (7) } \\
\text { Needs Improvement }(6 \text { or }<6)\end{array}$ & 10 \\
\hline $\begin{array}{l}\text { Response \#3 is made to classmate with the required length. } \\
\text { Response addresses the assignment requirement. }\end{array}$ & $\begin{array}{l}\text { Excellent (10) } \\
\text { Quality (9) } \\
\text { Good (8) } \\
\text { Fair (7) } \\
\text { Needs Improvement }(6 \text { or }<6)\end{array}$ & 10 \\
\hline
\end{tabular}

Martin and Bolliger's (2018) ${ }^{[13]}$ study found students could achieve greater satisfaction and motivation by simply improving student engagement. Online distance programs may leave students feeling isolated at times so it is important for faculty to recognize this may occur but faculty have the ability to reduce student isolation by creating assignments which promote greater student interaction, use of videos for introductions and assignment and online meeting/learning platforms in real time. Martin and Bolliger's ${ }^{[13]}$ study found greater student engagement and less feelings of isolation when faculty used meet and greet introductions, collaborative assignments, and a variety of communication strategies to help students connect to each other. The most advantageous strategies to assist faculty to engage with students were grading rubrics, regular announcements and email reminders for assignments. ${ }^{[13]}$ Students also seek real world issues to work on, meaningful assignments (apply to their work) and assignments which are exciting and thought provoking. ${ }^{[13]}$

\section{Quality Communication}

Lack of prompt feedback ${ }^{[3,4]}$ and poor communication ${ }^{[14]}$ are listed as frustrations from students when learning in an online environment. Communication is an important aspect of the student faculty relationship and poor communication may result in student dissatisfaction with a course and program of study ${ }^{[13]}$ It may be important to determine how students want to communicate with each other and with faculty. Many students today communicate through texting but might still appreciate a personal phone call or a video real time or web chat platforms. Faculty will need to be specific about where important course communication is going to be located so students know where to check for course updates and this is a way for faculty to hold students accountable for specific information.

\section{Conclusion}

The three-article series discusses strategies for innovative teaching and learning. This second article focused on how to deliver a distance online course. A working knowledge of the learning platform, developing a standard course model, creating rubrics, requiring active participation, and establishing quality communication is all key to the success of the online course. The third, and final article, in the series will give practical tips on connecting students from a distance including regular announcements, video conferencing, video updates, scheduled phone calls, and office hours.

\section{CONFLiCTS OF INTEREST Disclosure}

The authors declare that there is no conflict of interest.

\section{REFERENCES}

[1] Hicks T, Heastie S. High school to college transition: A profile of the stressors, physical and psychological health issues that af- fect the first-year on-campus college student. Faculty Working Papers from the School of Education. 2008. Available from: https : //digitalcommons.uncfsu.edu/soe_faculty_wp/14 
[2] Fawaz M. E-learning: Depression, anxiety, and stress symptomatology among Lebanese university students during COVID-19 quarantine. Nursing Forum. 2021; 56: 52-57. PMid:33125744 https: //doi.org/10.1111/nuf.12521

[3] Hara N, Kling R. Student distress in web-based distance education. Educause Quarterly. 2001; 68-69. Available from: https://er.educause.edu/-/media/files/articles/200 1/9/eqm01312.pdf

[4] Hara N, Kling R. Students' distress with a web-based distance education course: An ethnographic study of participants' experiences. The Turkish Online Journal of Distance Education. 2003.

[5] Panadero E, Jonsson A. The use of scoring rubrics for formative assessment purposes revisited: A review. Educational Research Review. 2013; 9: 129-144. https ://doi .org/10.1016/j. edurev . 2013. 01.002

[6] Billings D, Halstead J. Teaching in Nursing: A Guide for Faculty. Saunders Elsevier. 2009.

[7] Ragupathi K, Lee A. Beyond fairness and consistency in grading: The role of rubrics in higher education. In Sanger C., Gleason N (eds) Diversity and Inclusion in Global Higher Education. 2020. Palgrave Macmillan, Singapore. Available from: https ://link. springer. com/chapter/10.1007/978-981-15-1628-3_3 https://do i.org/10.1007/978-981-15-1628-3_3
[8] University of Texas at Austin. Faculty Innovation Center. What is a rubric? 2017. Available from: https://facultyinnovate.utex as.edu/sites/default/files/build-rubric.pdf

[9] Quality Matters. QM Rubrics \& Standards. 2021. Available from: https://www.qualitymatters.org/qaresources/rub ric-standards

[10] Dixson M. Creating effective student engagement in online courses: What do students find engaging? Journal of the Scholarship of Teaching and Learning. 2010; 10(2): 1-13.

[11] King I. Curriculum and instruction in nursing. East Norwalk, CT. 1986. (out of print).

[12] Peplau H. Interpersonal relations in nursing. Spring Publishing: New York 1988.

[13] Martin F, Bolliger DU. Engagement matters: Student perceptions on the importance of engagement strategies in the online learning environment. Online Learning. 2018; 22(1): 205-222. https: //doi.org/10.24059/olj.v22i1.1092

[14] Baticulon R, Sy J, Alberto N, et al. Barriers to Online Learning in the Time of COVID-19: A National Survey of Medical Students in the Philippines. Medical Science Education. 2021. PMid:33649712 https://doi.org/10.1007/s40670-021-01231-z 